\title{
SISTEM PAKAR DIAGNOSA PENYAKIT RUBEOLA PADA ANAK MENGGUNAKAN METODE FORWARD CHAINING DENGAN BAHASA PEMPOGRAMAN PHP \& DATABASE MYSQL
}

\author{
Agung Ramadhanu 1, Rizky Gusrianto ${ }^{2}$ \\ Sistem Informasi,Universitas Putra Indonesia"YPTK",Padang \\ Konsentrasi : Sistem Informasi Industri \\ E-mail: agung_ramadhanu@ upiyptk.ac.id, rizkygusrianto17@gmail.com
}

\section{Abstrak}

Campak adalah penyakit yang disebabkan oleh virus campak. Di Indonesia, jumlah kasus penyakit ini meningkat di akhir tahun 2014. Gejala klinis terdiri dari tiga stadium, yaitu stadium prodromal, eksantem, dan konvalesens. Diagnosis ditegakkan dengan anamnesis, pemeriksaan fisik, serta pemeriksaan antibodi IgM campak dalam darah. Tatalaksana bersifat suportif disertai pemberian vitamin A. Komplikasi yang sering menyebabkan kematian pada anak adalah pneumonia. Pencegahan dapat dilakukan dengan pemberian vaksin.

Kata kunci: Sistem Pakar, Rubeola, Forward Chaining, PHP, MySql

\section{Pendahuluan}

Pada saat ini perkembangan teknologi sudah sangat pesat, tidak hanya pada bidang informasi, industri, pendidikan, tetapi pada bidang kedokteran. Para ahli terus mengembangkan perkembangan teknologi yang ada, sehingga dengan adanya teknologi tersebut para ahli merasa terbantu dalam menyelesaikan pekerjaannya. Implementasi yang bisa diterapkan dalam bidang kedokteran salah satunya adalah sistem pakar diagnosa penyakit rubeola pada anak. Aplikasi ini digunakan untuk mendiagnosa gangguan pada gejala penyakit rubeola pada anak. Peran dokter sangat dibutuhkan tetapi pekerjaan dokter terbentur dengan keterbatasannya dalam melakukan konsultasi penyakit antara dokter dengan pasiennya, karena jumlah pasien yang banyak dan keterbatasan waktu serta fisik dari dokter itu sendiri. Rubeola adalah penyakit menular yang disebabkan oleh virus. Dikenal juga sebagai campak Jerman, yang biasanya menyerang anakanak dan remaja. Rubeola sendiri merupakan penyakit yang berbeda dari campak, tetapi memiliki kesamaan karena sama-sama menyebabkan ruam kemerahan pada kulit. Oleh karna itu, maka diperlukan perancangan sebuah sistem yang dapat meniru cara berfikir seorang pakar yang bisa berkonsultasi sesuai dengan diagnosa dan gejala-gejala yang telah dibuat di website. Dengan kecerdasan buatan komputer dapat melakukan hal-hal yang sebelumnya hanya dilakukan oleh manusia. Manusia dapat menjadikan komputer sebagai pegambil keputusan berdasarkan cara kerja otak manusia dalam mengambil keputusan. Salah satu cabang dari kecerdasan buatan (artificial Innteligence) yang banyak mendapat perhatian dari para ilmu saat ini adalah sistem pakar. Salah satu yang dipelajari pada kecerdasan buatan adalah sistem pakar dengan menggunakan metode Forward Chaining.

\section{Tinjauan Literatur}

\subsubsection{Tinjauan Umum Tentang}

\section{Sistem Informasi}

Sistem adalah suatu jaringan kerja dari prosedur-prosedur yang saling berhubungan, berkumpul bersama-sama untuk melakukan suatu kegiatan atau untuk menyelesaikan suatu sasaran yang tertentu (Jogiyanto, 2005:1). Definisi informasi menurut Jogiyanto dalam buku dapat diartikan sebagai data yang diolah menjadi 
bentuk yang lebih berguna dan lebih berarti bagi yang menerimanya (Jogiyanto, 2005:8). Definisi sistem informasi dalam bukunya Abdul Kadir yang berjudul Pengenalan Sistem Informasi, yaitu "sistem informasi adalah kerangka kerja yang mengkoordinasikan sumber daya (manusia, komputer) untuk mengubah masukan (input) menjadi keluaran (informasi), guna mencapai sasaran-sasaran perusahaan" (Kadir, 2003:11).

\subsubsection{Definisi Kecerdasan Buatan}

Kecerdasan buatan atau biasa di sebut Artificial Intelligence (AI) adalah salah satu bidang terbaru dalam dunia sains dan teknik. Menurut Russell \& Norvig (2010:1):

AI mulai dikerjakan sungguh-sungguh setelah Perang Dunia II, dan nama AI sendiri tercipta pada tahun 1956.

\subsubsection{Pengertian Sistem Pakar}

Secara umum Turban, et al (2005), Sistem Pakar adalah sistem yang berusaha mengadopsi pengetahuan manusia ke komputer yang dirancang untuk memodelkan kemampuan menyelesaikan masalah seperti layaknya seorang pakar. Dalam penyusunannya, sistem pakar mengombinasikan kaidah-kaidah penarikan kesimpulan atau inference rules dengan basis pengetahuan tertentu yang diberikan oleh satu atau lebih pakar dalam bidang tertentu. Kombinasi tersebut disimpan dalam komputer, yang selanjutnya digunakan dalam proses pengambilan keputusan untuk penyelesaian masalah tertentu.

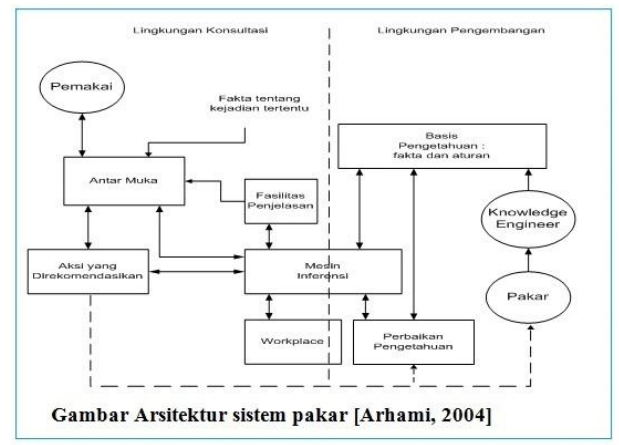

Gambar 2.1 Arsitektur Sistem Pakar

\subsubsection{Unified Modelling Language (UML)}

Sukamto dan Shalahuddin (2013:133), "UML (Unified Modeling Language) adalah salah satu standar bahasa yang banyak digunakan di dunia industri untuk mendefinisikan requirement, membuat analisis dan desain, serta menggambarkan arsitektur dalam pemrograman berorientasi objek".

Widodo dan Herlawati (2011:6), menyatakan bahwa "UML singkatan dari Unified Modeling Language yang berarti bahasa pemodelan standar. UML juga dapat diartikan sebagai bahasa yang memiliki sintaks dan semantik". UML menyediakan serangkaian gambar dan diagram yang sangat baik. Beberapa diagram memfokuskan diri pada ketangguhan teori object-oriented dan sebagian lagi memfokuskan pada detail rancangan dan konstruksi. Semua dimaksudkan sebagai sarana komunikasi antar team programmer maupun dengan pengguna.

Widodo dan Herlawati (2011:6-7), UML diaplikasikan untuk maksud tertentu, biasanya antara lain untuk :

a. Merancang perangkat lunak.

b. Sarana komunikasi antara perangkat lunak dengan proses bisnis.

c. Menjabarkan sistem secara rinci untuk analisa dan mencari apa yang diperlukan sistem.

d. Mendokumentasi sistem yang ada, proses-proses dan organisasinya.

Tabel 2.1 Tipe Diagram UML

\begin{tabular}{|l|l|l|}
\hline No & \multicolumn{1}{|c|}{ Diagram } & \multicolumn{1}{|c|}{ Tujuan } \\
\hline 1. & Class & $\begin{array}{l}\text { Memperlihatkan himpunan kelas- } \\
\text { kelas, antarmuka-antarmuka, } \\
\text { kolaborasi-kolaborasi, serta } \\
\text { relasi-relasi. }\end{array}$ \\
\hline 2. & Package & $\begin{array}{l}\text { Memperlihatkan kumpulan kelas- } \\
\text { kelas, merupakan dari diagram } \\
\text { komponen. }\end{array}$ \\
\hline 3. & Use case & $\begin{array}{l}\text { Diagram ini memperlihatkan } \\
\text { himpunan use case dan aktor- } \\
\text { aktor (suatu jenis khusus dari } \\
\text { kelas). }\end{array}$ \\
\hline 4. & Sequence & $\begin{array}{l}\text { Diagram interaksi yang } \\
\text { menekankan pada pengiriman } \\
\text { pesan dalam suatu waktu tertentu. }\end{array}$ \\
\hline
\end{tabular}




\begin{tabular}{|l|l|l|}
\hline 5. & Communication & $\begin{array}{l}\text { Sebagai pengganti diagram } \\
\text { kolaborasi UML1.4 yang } \\
\text { menekankan organisasi struktural } \\
\text { dari obyek-obyek yang menerima } \\
\text { serta mengirim pesan. }\end{array}$ \\
\hline 6. & Statechart & $\begin{array}{l}\text { Diagram status memperlihatkan } \\
\text { keadaan-keadaan pada sistem, } \\
\text { memuat status (state), transisi, } \\
\text { kejadian serta aktivitas. }\end{array}$ \\
\hline 7. & Activity & $\begin{array}{l}\text { Tipe khusus dari diagram status } \\
\text { yang memperlihatkan aliran dari } \\
\text { suatuaktivitas ke aktivitas lainnya } \\
\text { dalam suatu sistem. }\end{array}$ \\
\hline 8. & Component & $\begin{array}{l}\text { Memperlihatkan organisasi serta } \\
\text { kebergantungan sistem } \\
\text { perangkat lunak pada komponen- } \\
\text { komponen yang telah ada } \\
\text { sebelumnya. }\end{array}$ \\
\hline 9. & Deployment & $\begin{array}{l}\text { Memperlihatkan konfigurasi saat } \\
\text { aplikasi dijalankan (run-time). }\end{array}$ \\
\hline
\end{tabular}

Sumber : Widodo dan Herlawati (2011:10-

12)

\section{Hasil dan Diskusi}

\subsection{Tabel Data Penyakit dan Solusinya.}

\begin{tabular}{|c|c|c|}
\hline $\begin{array}{c}\text { Kode } \\
\text { Penya } \\
\text { kit }\end{array}$ & $\begin{array}{c}\text { Nama } \\
\text { Penyakit }\end{array}$ & Solusi \\
\hline P001 & $\begin{array}{l}\text { Rubella(rube } \\
\text { ola) }\end{array}$ & $\begin{array}{l}\text { Pengobatan rubella cukup } \\
\text { dilakukan di rumah, karena } \\
\text { gejalanya tergolong ringan. } \\
\text { Dokter akan meresepkan } \\
\text { obat paracetamol guna } \\
\text { meringankan nyeri dan demam, } \\
\text { serta menyarankan pasien untuk } \\
\text { banyak beristirahat di rumah, agar } \\
\text { virus tidak menyebar ke orang } \\
\text { lain. } \\
\text { Pada ibu hamil yang menderita } \\
\text { rubella, dokter mungkin akan } \\
\text { meresepkan } \\
\text { antibodi hyperimmune } \\
\text { globulin untuk melawan virus. } \\
\text { Meski dapat mengurangi gejala, } \\
\text { antivirus tidak mencegah } \\
\text { kemungkinan bayi menderita } \\
\text { sindom rubella kongenital, yaitu } \\
\text { suatu kondisi yang menyebabkan } \\
\text { bayi terlahir dengan kelainan. }\end{array}$ \\
\hline P002 & Ruseola & $\begin{array}{l}\text { Roseola biasanya bisa pulih } \\
\text { dengan sendirinya. Kondisi ini } \\
\text { jarang menimbulkan komplikasi. } \\
\text { Namun, pada beberapa kondisi, } \\
\text { roseola bisa meningkatkan risiko } \\
\text { terjadinya infeksi telinga atau } \\
\text { kejang demam. } \\
\text { Sedangkan pada anak dengan } \\
\text { daya tahan tubuh yang lemah, } \\
\text { misalnya anak dengan gizi } \\
\text { buruk atau yang baru menerima } \\
\text { transplantasi organ, dapat terjadi } \\
\text { komplikasi serius, seperti radang } \\
\text { otak dan pneumonia. }\end{array}$ \\
\hline P003 & $\begin{array}{l}\text { Demam } \\
\text { Scarlet }\end{array}$ & $\begin{array}{l}\text { Umumnya penderita sembuh } 4-5 \\
\text { hari setelah diobati. Untuk } \\
\text { menangani demam scarlet, dokter } \\
\text { akan memberikan antibiotik } \\
\text { minum, seperti penisilin, selama } \\
10 \text { hari. Pada penderita yang } \\
\text { alergi penisilin, dokter dapat } \\
\text { meresepkan erythromycin sebagai }\end{array}$ \\
\hline
\end{tabular}

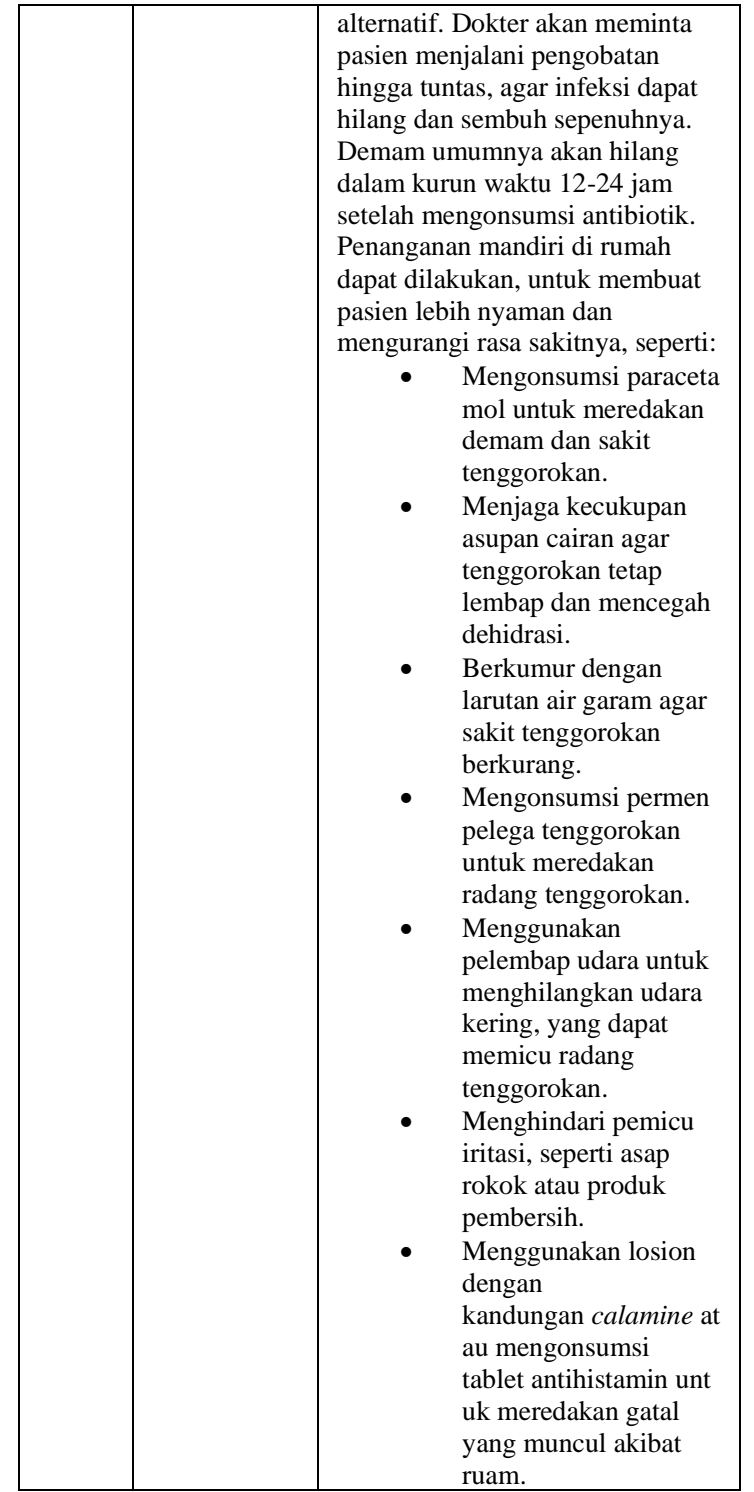

4.10 Tabel Data Gejala Penyakit

\begin{tabular}{|c|c|c|c|c|}
\hline Id & $\begin{array}{c}\text { Kode } \\
\text { Penyaki } \\
\mathrm{t}\end{array}$ & Nama Penyakit & $\begin{array}{c}\text { Kode } \\
\text { Gejal } \\
\mathrm{a} \\
\end{array}$ & Gejala \\
\hline 1. & P001 & $\begin{array}{c}\text { Rubella(Rubeola } \\
\text { ) }\end{array}$ & G001 & Demam \\
\hline 2. & P001 & $\begin{array}{c}\text { Rubella(Rubeola } \\
\text { ( }\end{array}$ & G004 & $\begin{array}{c}\text { Peradangan } \\
\text { membran } \\
\text { rongga } \\
\text { hidung } \\
\end{array}$ \\
\hline 3. & P001 & $\begin{array}{c}\text { Rubella(Rubeola } \\
\text { ) }\end{array}$ & G007 & Mata merah \\
\hline 4. & P001 & $\begin{array}{c}\text { Rubella(Rubeola } \\
\text { ) }\end{array}$ & G009 & Batuk \\
\hline 5. & P001 & $\begin{array}{c}\text { Rubella(Rubeola } \\
\text { ) }\end{array}$ & G011 & $\begin{array}{c}\text { Mata berair } \\
\text { dan sensitif } \\
\text { terkena } \\
\text { cahaya }\end{array}$ \\
\hline 6. & P001 & $\begin{array}{c}\text { Rubella(Rubeola } \\
\text { ) }\end{array}$ & G015 & $\begin{array}{l}\text { Bercak- } \\
\text { bercak }\end{array}$ \\
\hline 7. & P002 & Ruseola & G002 & $\begin{array}{c}\text { Nafsu } \\
\text { makan turun }\end{array}$ \\
\hline 8. & $\mathrm{P} 002$ & Ruseola & G009 & Batuk \\
\hline 9. & $\mathrm{P} 002$ & Ruseola & G012 & Pilek \\
\hline 10 & P002 & Ruseola & G018 & $\begin{array}{c}\text { Kelopak } \\
\text { mata } \\
\text { membengka } \\
\mathrm{k} \\
\end{array}$ \\
\hline
\end{tabular}




\begin{tabular}{|c|c|c|c|c|}
\hline 11 & P002 & Ruseola & G024 & $\begin{array}{c}\text { Sakit } \\
\text { tenggorokan }\end{array}$ \\
\hline 12 & $\mathrm{P} 002$ & Ruseola & G025 & $\begin{array}{c}\text { Demam } \\
\text { tinggi }\end{array}$ \\
\hline 13 & P002 & Ruseola & G026 & diare \\
\hline 14 & P003 & Demam Scarlet & G014 & Sakit kepala \\
\hline 15 & P003 & Demam Scarlet & G017 & $\begin{array}{c}\text { Mual/munta } \\
\text { h }\end{array}$ \\
\hline 16 & P003 & Demam Scarlet & G019 & $\begin{array}{c}\text { Sulit } \\
\text { menelan }\end{array}$ \\
\hline 17 & P003 & Demam Scarlet & G020 & Pucat \\
\hline 18 & P003 & Demam Scarlet & G021 & $\begin{array}{c}\text { Demam } \\
\text { tinggi }\end{array}$ \\
\hline 19 & P003 & Demam Scarlet & G022 & $\begin{array}{c}\text { Lidah } \\
\text { stoberi }\end{array}$ \\
\hline 20 & P003 & Demam Scarlet & G023 & $\begin{array}{l}\text { Wajah dan } \\
\text { leher } \\
\text { memerah }\end{array}$ \\
\hline
\end{tabular}

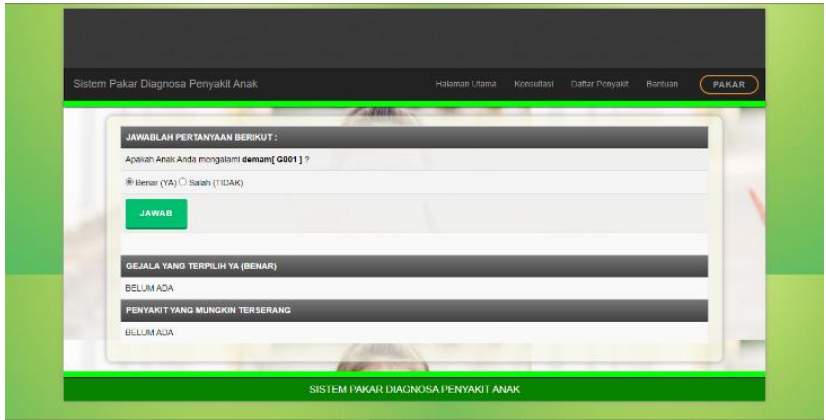

Gambar 4.3 tampilan pertanyaan pada konsultasi

Pasien diminta untuk menjawab beberapa pertanyaan dari gejala yang diraskan pasien

\section{Interface}

Interface berisi tampilan program sistem pakar dan langkah - langkah menggunakan seperti dibawah ini:

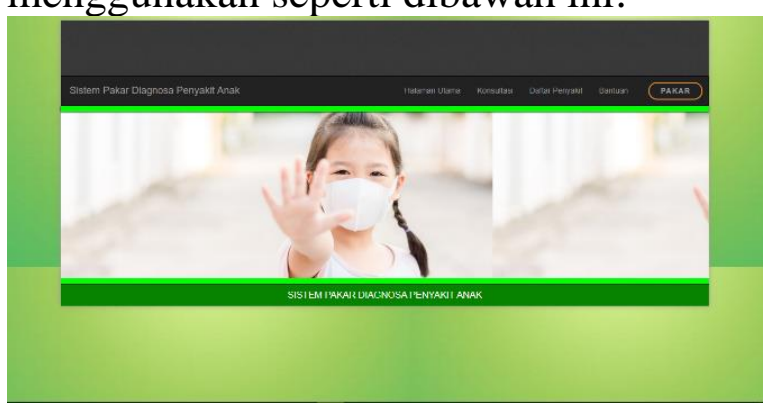

Gambar 4.1 tampilan home

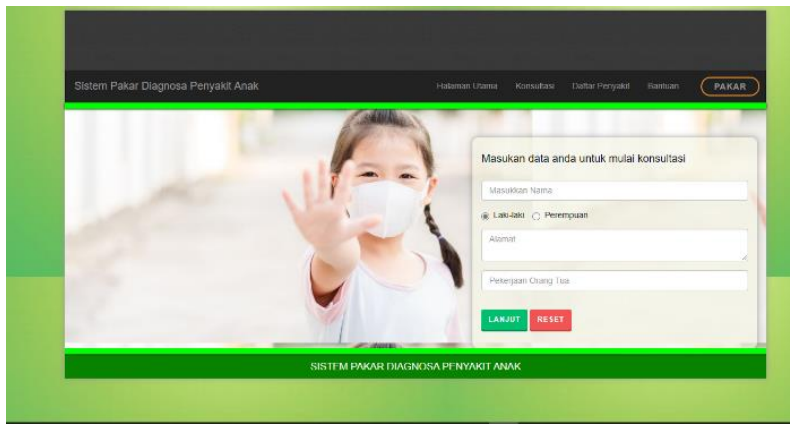

Gambar 4.2 tampilan registrasi

Setelah berhasil input data, pasien bisa lanjut pada halaman konsultasi

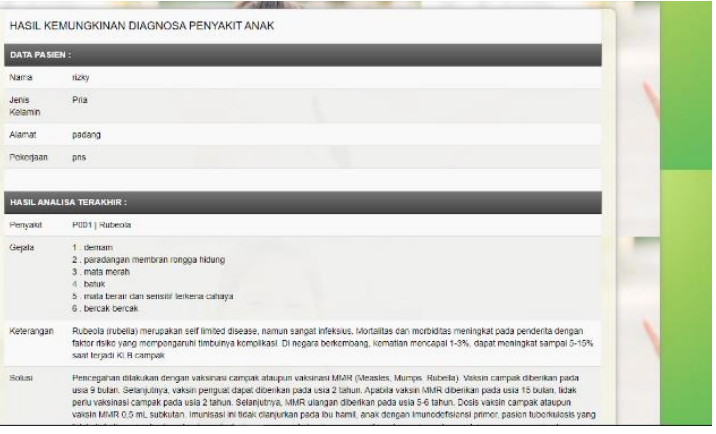

Gambar 4.4 tampilan hasil konsultasi

\subsection{Kesimpulan}

Berdasarkan hasil yang didapat dari pembahasan sistem pakar untuk diagnosa penyakit rubeola pada anak dengan metode forward chaining, maka dapat diambil beberapa kesimpulan sebagai berikut :

1. Dengan diterapkan bahasa pemrograman PHP dalam sistem pakar untuk diagnosa penyakit rubeola pada anak dapat membantu dokter anak pada Klinik Fitria dalam mengetahui penyakit yang diderita oleh pasien dengan cepat dan disertai dengan solusi, sehingga pasien tidak perlu menunggu lama untuk mengetahui penyakit apa yang dideritanya.

2. Sistem pakar dilengkapi dengan informasi singkat mengenai penyakit rubeola pada anak, gejala, penyebab dan solusi penyakit rubeola pada anak. Sistem yang dirancang dengan menggunakan bahasa pemrograman PHP dan 
database XAMPP MySQL dapat memberikan kemudahan kepada pihak Klinik Fitria terutama dokter dalam mendeteksi penyakit rubeola pada anak.

\section{Refrensi}

Dhiaksa, Anindita. 2016. Sistem Pakar Diagnosa Penyakit Kulit Menggunakan Metode Forward Chaining. Program Studi Teknik Informatika: Tugas Akhir Diterbitkan

Kurniawan, Budi. 2011. Aplikasi Sistem Pakar Berbasis Web Untuk Diagnosa Penyakit Gigi dan Mulut. Program Studi Teknik Informatika: Tugas Akhir Diterbitkan

Soegijanto S, Salimo H. Campak. In: Ranuh IGNG, Suyitno H, Hadinegoro SRS, Kartasasmita CB, Ismoedijanto, Soedjatmiko. Pedoman imunisasi di Indonesia. 4th ed. Jakarta: Badan Penerbit

Meriska, Melfi. 2018. Membangun Sistem Informasi Laporan Laba Rugi dan Laporan Grafik Penjualan Pada Toko Mas Jaya Baru Dengan Menggunakan Bahasa Pemrograman Java Netbeans dan MySQL. Program Sarjana Komputer: Laporan PKL Tidak Diterbitkan

11. Info Imunisasi. Campak bisa dicegah dengan imunisasi [image on the Internet]. 2012 July

Maldonado YA. Rubeola virus (measles and subacute sclerosing panencephalitis). In: Long SS, Pickering LK, Prober CG, editors. Principles and practice of pediatric infectious diseases. 4th

Suendri. 2018. "Implementasi Diagram UML (Unified Modelling Language) Pada Perancangan Sistem Informasi Remunerasi Dosen Dengan Database Oracle". Jurnal Ilmu Komputer dan Informatika. 03(01), 19 